\title{
Satisfaction Assessment on the Counseling Service System for Full-Time Teacher-Counselor in Tainan Elementary School
}

\author{
Hsiu-Hao Liu \\ The Ph.D. Program in Business and Operations Management, College of Management, \\ Chang Jung Christian University \\ No.1,Changda Rd., Gueiren District, Tainan City, 711301, Taiwan \\ Yun-Syuan Jhang \\ Department Of Counseling and Guidance, National University of Tainan \\ No.33, Sec. 2, Shu-Lin St., Tainan City, 700301, Taiwan \\ E-mail: harry2356969@gmail.com,s16784@hotmail.com
}

\begin{abstract}
As the most important case management system in the school counseling work, the counseling service system must meet the needs and expectations of the school teacher-counselors (the main users). This investigation uses the questionnaire survey method aimed at teacher-counselors in elementary schools in Tainan City to understand the degree of teacher-counselors' satisfaction when they use the counseling service system. The results mainly found that counselor-teachers were most satisfied with "The items provided by the system website are completed and various." followed by "The items provided by the system website are necessary items meeting the needs for counseling work." while the least satisfactory item was "Using the system website helps me communicate and interact with others in counseling work." In the five satisfaction aspects of the system, the perceived ease of use and the usage attitude were found to be effective in explaining the system usage intention. Some practical implications of this research as well as topics worthy of further research were discussed at the conclusion of the research.
\end{abstract}

Keywords: Perceived Usefulness, Perceived Ease of Use, Counseling Service System, Teacher-Counselor

\section{Introduction}

The counseling service system is the most important tool for case management in counseling work in the junior high and elementary schools in Tainan City. The purpose of the system design is to assist school teacher-counselors to care for students and track their psychological development, and hope that students will have good adaptive growth. The school teachercounselors are the main users of using the system. In addition to daily counseling affairs, the school teachercounselors also use the system to record the background information, counseling records, referrals and other operations of the case. In actual use, the school teacher-counselors find that they have encountered difficulties and doubts in the operation of the system, filling in items, and review procedures, and even ethical concerns about the leakage of personal data, which may endanger the relevant rights and protection of the case, and therefore also affect the system usage intention of the school teachercounselors.

This study is to explore the reasons why the school teacher-counselors accept or reject this system. It is 
based on the Technology Acceptance Model (TAM) (Davis, 1989) and refers to Ahmad and Khalid (2017), Elena and Detmar (1999), Luarn and Lin (2005), Moore and McElroy (2012), etc., used the five dimensions, these are system quality (SQ), system response time (SRT), perceived usefulness (PU), perceived ease of use (PEOU) and usage attitudes (UA), as the main factors to explore the system usage intention (SUI) of the school teacher-counselors.

The purpose of this study is to explore the current situation of the school teacher-counselors using the counseling service system, and to understand whether the school teacher-counselors are satisfied with the system and the system usage intention due to demographic characteristics (seniority, system using frequency, the average using time), there are differences depending on the difference, and then we will further explore whether the school teachercounselors satisfaction with the system can effectively explain the system usage intention, and follow-up discussion based on the results.

\section{Research Design}

The conceptual framework of this study is as follows:

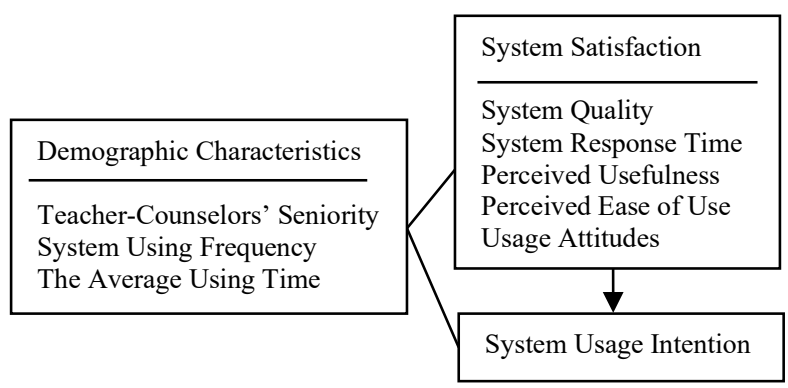

Fig. 1 Conceptual Framework

\section{2-1. Participant}

The main objects of this research are full-time teachercounselors in Tainan Elementary Schools, with a total of 90 teachers who voluntarily participated in answering questionnaires. Finally, 20 teachers submitted responses.

\section{2-2. Data Collection Instrument}

This research was based on the self-compiled "Questionnaire on the Status of Professional Counselors in Tainan Elementary Schools Using the
Counseling Service System" to conduct a survey, including demographic characteristics (4 questions), system satisfaction (18 questions) and system usage Intention (2 questions) consists of three parts, which are in the form of a Likert four-point scale. The higher the score, the higher the degree of satisfaction or system usage intention.

This questionnaire has a very good internal consistency reliability $(\alpha=.92)$. In terms of validity, 7 senior experts and scholars in the relevant fields, including information, counseling and education, and with seniority between 6 and 20 years are invited to conduct the survey. The content is appropriate for the discussion, so the research tools used in the research should have content validity.

Table 1. Experts and Scholars Background

\begin{tabular}{|c|c|c|c|}
\hline No. & Present Job & $\begin{array}{l}\text { Areas of } \\
\text { expertise }\end{array}$ & Seniority \\
\hline $\mathrm{A}$ & $\begin{array}{l}\text { University } \\
\text { Assistant } \\
\text { Professor }\end{array}$ & $\begin{array}{l}\text { Information } \\
\text { Management }\end{array}$ & 10 years \\
\hline B & $\begin{array}{l}\text { University } \\
\text { lecturer }\end{array}$ & $\begin{array}{l}\text { Information } \\
\text { Engineering }\end{array}$ & 8 years \\
\hline $\mathrm{C}$ & $\begin{array}{l}\text { Junior High } \\
\text { School Teacher- } \\
\text { Counselor }\end{array}$ & $\begin{array}{l}\text { Counseling } \\
\& \text { Education }\end{array}$ & 20 years \\
\hline $\mathrm{D}$ & $\begin{array}{l}\text { Junior High } \\
\text { School Teacher- } \\
\text { Counselor }\end{array}$ & $\begin{array}{l}\text { Counseling } \\
\text { \& Education }\end{array}$ & 11 years \\
\hline $\mathrm{E}$ & $\begin{array}{l}\text { Elementary } \\
\text { School Teacher- } \\
\text { Counselor }\end{array}$ & $\begin{array}{l}\text { Counseling } \\
\& \text { Education }\end{array}$ & 19 years \\
\hline $\mathrm{F}$ & $\begin{array}{l}\text { Elementary } \\
\text { School Teacher- } \\
\text { Counselor }\end{array}$ & Counseling & 6 years \\
\hline G & $\begin{array}{l}\text { Elementary } \\
\text { School Teacher- } \\
\text { Counselor }\end{array}$ & Counseling & 6 years \\
\hline
\end{tabular}

\section{Result}

\subsection{System Satisfaction Score}

The results of the elementary school teachercounselors satisfaction items are as follows: "The items provided by the system website are completed and various." ( $(\mathrm{M}=2.90)$, was the highest of all items. "The items provided by the system website are necessary items meeting the needs for counseling work." ( $\mathrm{M}=2.75)$ was secondly. The least satisfactory (C) The 2021 International Conference on Artificial Life and Robotics (ICAROB2021), January 21 to 24, 2021 
item was "Using the system website helps me communicate and interact with others in counseling work" $(\mathrm{M}=1.85)$. The second lowest is "I think the system helps me in the word processing of counseling work is more efficient and convenient" $(\mathrm{M}=1.90)$.

From the perspective of the five aspects, except for the system quality, the other aspects have the lowest scores, but none of the aspects have the highest scores. Observing the average score of the aspect again, it can be found that the school teacher-counselors are somewhat dissatisfied with the degree of satisfaction with the system

Table 2. Descriptive Statistics of System Usage Satisfaction

\begin{tabular}{lllll}
\hline $\begin{array}{l}\text { Dimension / } \\
\text { Full marks }\end{array}$ & M & SD & MIN & MAX \\
\hline SQ/24 & 15.65 & 1.79 & 11 & 18 \\
SRT/8 & 4.55 & 1.43 & 2 & 7 \\
PU/8 & 4.30 & 1.42 & 2 & 6 \\
PEOF/16 & 8.20 & 2.48 & 4 & 12 \\
UA/16 & 8.60 & 2.42 & 4 & 12 \\
\hline
\end{tabular}

\subsection{System Usage Intention Score}

In terms of the performance of the school teachercounselors in elementary schools, from the highest, lowest and average scores, it can be found that school teacher-counselors have a little low system usage intention.

Table 3. Descriptive Statistics of System Usage Intention

\begin{tabular}{lllll}
\hline $\begin{array}{l}\text { Dimension / } \\
\text { Full marks }\end{array}$ & M & SD & MIN & MAX \\
\hline SUI $/ 8$ & 4.15 & 1.50 & 2 & 6 \\
\hline
\end{tabular}

\subsection{Demographic Characteristics and System Satisfaction}

After performing a single-factor variance analysis, it is found that the system satisfaction, system quality, system response time, perceived usefulness, perceived ease of use and usage attitudes of the school teachercounselors.

There will be no difference due to age, frequency of use and average use time.
Table 4. Summary table of single factor variance analysis (System Satisfaction Dimensions)

\begin{tabular}{llll}
\hline Dimension & Seniority & $\begin{array}{l}\text { Usage } \\
\text { Frequency }\end{array}$ & $\begin{array}{l}\text { Average } \\
\text { Use Time }\end{array}$ \\
\hline SQ & .61 & 2.85 & .50 \\
SRT & 1.13 & 1.22 & .02 \\
PU & 1.61 & 1.89 & .04 \\
PEOU & 2.03 & 2.16 & .42 \\
UA & .59 & 1.51 & .02 \\
\hline
\end{tabular}

\subsection{Demographic Characteristics and System Usage Intention}

A single-factor analysis of variance found that the system usage intention of the elementary school teacher-counselors does not depend on seniority $(\mathrm{F}=1.48, \mathrm{p}>.05)$, usage frequency $(\mathrm{F}=2.48, \mathrm{p}>.05)$ and average use time $(\mathrm{F}=.00, \mathrm{p}>.05)$.

Table 5. Summary table of single factor variance analysis (System Usage Intention)

\begin{tabular}{llll}
\hline Dimension & Seniority & $\begin{array}{l}\text { Usage } \\
\text { Frequency }\end{array}$ & $\begin{array}{l}\text { Average } \\
\text { Use Time }\end{array}$ \\
\hline SUI & 1.48 & 2.48 & .00 \\
\hline
\end{tabular}

\subsection{System Satisfaction and System Usage Intention}

System satisfaction and system usage intention. are related to the Pearson product difference. It is found that there is a high positive correlation between the two $(\mathrm{r}=.89, \mathrm{p}<.01)$, and four of the five dimensions are significantly correlated $(\mathrm{r}=.71 \sim .87, \mathrm{p}<.01)$. Only the system reaction time and the willingness to use the system are not significantly correlated $(\mathrm{r}=.33$, $\mathrm{p}>$.05). It shows that in the usage intention of the school teacher-counselors to use the system, compared with other aspects, the system response time is not the main consideration.

Table 6. Correlations between the Variables of the Study

\begin{tabular}{lllllll}
\hline & SQ & SRT & PU & PEOF & UA & SUI \\
\hline SQ & - & $.55^{*}$ & $.61^{* *}$ &. $.52^{*}$ & $.66^{* *}$ & $.71^{* *}$ \\
SRT & & - & .43 & .38 & .20 & .33 \\
PU & & & - & $.89^{* *}$ & $.76^{* *}$ & $.87^{* *}$ \\
PEOF & & & & - & $.81^{* *}$ & $.83^{* *}$ \\
UA & & & & & - & $.85^{* *}$ \\
SUI & & & & & - \\
\hline
\end{tabular}


$* * \mathrm{p}<.01, * \mathrm{p}<.05$

Carry out multiple regression analysis based on the five dimensions of system satisfaction and system usage intention, and use stepwise regression as the method of regression model to screen predictive variables. It is found that the two dimensions of perceived usefulness and usage attitude in the degree of system satisfaction can effectively explain the system usage intention (multiple $\mathrm{R}^{2}=.84$, adjusted $\left.\mathrm{r}^{2}=.82, \mathrm{p}<.01\right)$. It shows that there may be key factors in the system usage intention of the school teachercounselors in the two aspects.

Table 7. Summary table of multiple regression analysis coefficient

\begin{tabular}{llll}
\hline $\begin{array}{l}\text { Selected forecast } \\
\text { variables and } \\
\text { order }\end{array}$ & $\begin{array}{l}\text { Multiple } \\
\mathrm{R}^{2}\end{array}$ & $\begin{array}{l}\Delta \text { Multiple } \\
\mathrm{R}^{2}\end{array}$ & $\begin{array}{l}\Delta \mathrm{F}- \\
\text { value }\end{array}$ \\
\hline $\mathrm{PU}$ & .76 & .76 & $56.37 * *$ \\
$\mathrm{UA}$ & .84 & .08 & $8.74 * *$ \\
\hline$* * \mathrm{p}<.01, * \mathrm{p}<.05$ & &
\end{tabular}

\section{Conclusion}

Based on the above results, it can be found that different seniority, usage frequency, average use time, the elementary school teacher-counselors are more dissatisfied with the degree of system satisfaction. Similarly, elementary school teacher-counselors with different background variables tend to be less system usage intention. In terms of this result, it can be seen that the current counseling service system is not trusted by the elementary school teacher-counselors, and it cannot help the school teacher-counselors to improve their work efficiency or improve the timeconsuming trouble of paper processing. It is difficult to obtain the expected benefits in practice.

The main factors influencing the system usage intention are related to the two dimensions of perceived ease of use and usage attitudes. From the items of the two dimensions, it can be found that there may be difficulties in learning to operate the counseling service system, and the security of the system cannot be trusted by the school teachercounselors. These results show that there was a lack of guidance and communication when the system was launched, and no good consultation channels were provided. What is more worthy of discussion is the management of information security. Since school counseling work has a fairly strict principle of confidentiality, the use of any information is regulated by law.

From this result, it can be found that the school teacher-counselors have great concerns about data preservation or management.

In order to explore the critical factors of the school teacher-counselors system usage intention, this research will conduct qualitative research, integrate the results, and provide the results to relevant agencies to improve the counseling service system.

\section{References}

1. Ahmad, S. Z., \& Khalid, K. (2017). The adoption of m-government services from the user's perspectives: Empirical evidence from the United Arab Emirates. International Journal of Information Management, 37(5), 367-379.

2. Davis, F. D. (1989). Perceived usefulness, perceived ease of use, and user acceptance of information technology. MIS Quarterly, 13(3), 319-340.

3. Davis, F. D., Bagozzi, R. P., \& Warshaw, P. R. (1989). User acceptance of computer technology: A comparison of two theoretical models. Management Science, 35(8), 982-1003.

4. Elena, K., \& Detmar, W.S. (1999).The psychological origins of perceived usefulness and ease-of-use. Information \& Management, 35, 237-250.

5. Luarn, P., \& Lin, H. H., (2005), Toward an Understanding of the Behavioral Intention to Use Mobile Banking. Computers in Human Behavior, 21(6), 873-891.

6. Moore, K., \& McElroy, J. C. (2012). The influence of personality on Facebook usage, wall postings, and regret. Computers in Human Behavior, 28(1), 267- 274. 